\title{
TOTAL BACTERIAL COUNT, SOMATIC CELL COUNT AND PRESENCE OF AFLATOXIN M1 IN RAW MILK FROM THE “OVČE POLE” REGION, REPUBLIC OF NORTH MACEDONIA
}

\author{
Sanja Kostadinović Veličkovska ${ }^{1 *}$, Zoran Arsevski', Daniela Dimovska ${ }^{1}$, Fidanka Ilieva ${ }^{1}$, \\ Aco Kuzelov ${ }^{1}$ \\ 'Faculty of Agriculture, Goce Delcev University, Krste Misirkov bb, 2000 Stip, \\ Republic of North Macedonia \\ *Corresponding author: sanja.kostadinovik@ugd.edu.mk
}

\begin{abstract}
Dairy product quality monitoring begins at the farm and ends in the hands of the consumer. Raw milk must also meet other quality standards; it should be free of drug residues, free of added water and free of sediment, contaminants and other abnormalities. In our researches, is taken somatic cells count, the number of bacteria and Aflatoxins as indicators of the quality of raw milk from the Ovče Pole region in the period JanuaryJune, 2018. For the needs of this research, an analysis was made of 1320 samples for the presence of bacteria in raw milk, determination of somatic cell count in 478 samples as well as identification and quantification of aflatoxin $\mathrm{M} 1$ in 60 samples.

The results from this study indicated determination acceptable count of somatic cells in $95.5 \%$ of the samples from raw milk while in 2 samples of raw milk, the amount of aflatoxin M1 was above limits with highest amount of $0.58 \mathrm{mg} / \mathrm{kg}$ raw milk. According to European milk quality standards, in the biggest part of the samples $(89.55 \%)$, presence of bacteria does not meet the standard. From the analyses made by the milk producers that were the subject of analysis in this research, it can be concluded that they do not adhere to good agricultural practice, the level of milk contamination is high due to poor hygiene, improper handling of milk after milking and insufficient education of farmers for hygiene in primary production.
\end{abstract}

Keywords: raw milk, total bacteria count, somatic cells, aflatoxin M1

\section{INTRODUCTION}

Somatic cell count is the common method for determination of raw milk quality (Bansal et al., 2005). An increased amount of somatic cells results either from an inflammatory process due to the presence of an intramammary infection or, under non-pathological conditions, from physiological processes such as estrus or advanced stage of lactation (Batavani et al., 2007). Monitoring of somatic cell numbers has been simplified by automated cell counters that allow large numbers of milk samples to be evaluated quickly. The number of somatic cells, usually called somatic cell count, in milk is used as an important indicator of udder health since somatic cells are involved in protecting the mammary gland from infection as part of the innate immune system. SCC in milk is influenced by many factors, such as animal species, milk production level, lactation stage, and also the individual and environmental factors as well as management practices. The selection of dairy animals for greater milk production and the removal of milk by machine milking impose unnatural stress on the bovine udder. This has increased the chances of mammary infections in these animals. To defend against the mammary infections, somatic cells (SCs) are released into the milk. These cells not only fight infection but also repair tissue damage. All the developed countries are using milk somatic cell counts (SCCs) as a marker to monitor the prevalence of mastitis in dairy herds, as an indicator of raw milk quality to processors, and also as a more general indicator of the hygienic conditions of milk production on farms. Though somatic cell count is subjected to variation, it is still used as 
an indicator of milk quality in several species, especially in ruminant and human. Generally, SCs until now have been considered as negative. High SCC is associated with udder inflammation, which leads to bacteriological problems in milk, an alteration of milk composition, and finally, the major modifications of dairy product characteristics compared to the normal values. The role of SCs is generally assessed as a global effect, although the influence of the other factors has not been considered separately, and then, includes intrinsic characteristics of milk modified by the inflammation of the mammary gland, consequences on milk biosynthesis and secretion, and bacterial count. Aflatoxins (AFs) are secondary metabolites produced by Aspergillus flavus, Aspergillus parasiticus, and Aspergillus nominus fungi under impropriate growing and storage conditions (Applebaum et al., 1982). There are 18 different known $A F s$, and AFB1 is the most toxic and can contaminate various foods (Aycicek et al., 2005). After ingestion, its high fat solubility favours gastrointestinal absorption and can reach the liver (Battacone et al., 2003), where it is metabolized by the cytochrome P450 enzyme family and is hydrolysed into Aflatoxin M1 (AFM1) or milk Aflatoxin (Decastelli et al., 2007). It is then transferred to milk (Diener et al., 2001) and, thus, to milk derivatives and products (Dragacci et al., 2001). The most common aflatoxin with proven cancerogenic effect in raw milk is aflatoxin M1. European Community (EC) and Codex Alimentarius prescribe a limit of $50 \mathrm{ng} / \mathrm{kg} \mathrm{AFM} 1$ in milk and $25 \mathrm{ng} / \mathrm{kg}$ for infant milk products. However, US regulation fixed the limit to a maximum of $500 \mathrm{ng} / \mathrm{kg}$ for milk and $25 \mathrm{ng} / \mathrm{kg}$ for infant milk products. The microbial milk contamination source comes from herd hygiene and health status, mastitis prevalence, production environment, and milking parlour and milk conserving practices in dairy farm. Other microbial contamination of milk possibility may occur during the long milk storage, under low insufficient temperature (Lin $\mathrm{H}$ et al., 2016). Usually, contaminated environments are a potential source of foodborne pathogens and spoilage bacteria present in raw milk bulk tank in the dairy farm, which are affecting the milk quality and emerging public health risk (Van Kessel JS et al., 2008, Viljoen BC,2001, Kagkli DM et al., 2007. External contamination of the udder can have a huge impact on the total number of bacteria. (Bramley and McKinnon. 1990). The study of risk factors associated with contamination of raw milk from Listeria monocytopenia's milk showed that insufficient cleanliness of cows, inadequate lighting of milking parlours and barns may be an indication of neglect of milking hygiene. Inadequate disinfection of towels used to dry the udder can significantly increase the likelihood of contamination (Sana et al., 2003).

Silage is also an important source of contamination with Listeria spp., including $L$. monocytogenes and other potential human pathogens such as Yersinia enterocolitica and Aeromonas hydrophila (Sana et al., 2003).

The aim of this work was screening of the quality of the raw milk for the period of JanuaryJune, 2018 by determination of total bacteria and somatic cell counts as well as quantification of aflatoxine M1. For this purpose, 1316 samples of raw milk were selected for investigation of total bacterial count, 478 samples were selected for determination of somatic cell count and 60 samples were collected for identification and quantification of aflatoxine M1.

\section{MATERIAL AND METHODS}

\section{Determination of somatic cell count and aflatoxin $\mathrm{M} 1$ in raw milk}

60 samples of raw milk from the farm in the region of "Ovče Pole" were the subject of the presence of aflatoxin M1 and somatic cell counts. All samples were stored at $2-8^{\circ} \mathrm{C}$ and tested for 24 hours. Some samples that we were not able to analyse within 24 hours were stored at $-20^{\circ} \mathrm{C}$. To determine the total number of bacteria in the period from January to June 2018, 1316 samples were taken, while to determine the number of somatic cells, 478 samples of raw milk from producers in the Ovce Pole region. Samples are taken and delivered in sterile plastic cups with a volume of $50 \mathrm{ml}$ canned by Adizol (Sigma-Aldrich vol. $25 \mathrm{ml}$ ). After taking, they were transported at a temperature of $4^{\circ} \mathrm{C}$ in the laboratory for testing the quality of raw milk at the Faculty of Veterinary Medicine Skopje. All samples are 
analysed by accredited method in accordance with ISO 21187: 2004. The instrument used for the tests was the Bactoscan 8000S (Foss Electric Denmark). The BMO procedure was performed according to the Milk-Quantitative determination of bacteriological quality, IDF Standard 161A: 1995. This device works on the principle of staining bacteria with fluorescent dye. In the procedure after staining the bacteria, a thin film of the milk sample is placed on a rotating disk under the lens of a fluorescent microscope. This microscope counts coloured bacteria as light pulses that are electronically converted and displayed as numerical data.

Before somatic cell counting, the samples are heated to $40^{\circ} \mathrm{C}$ and analysed twice on a Fossomatic 5000 (FossElectric, Denmark). The somatic cell counting procedure was performed in accordance with the accredited method ISO 17025-FVM-SOP-398 according to references from ISO 13366-2: 2006. ELISA equipment Immunoscreen AFM1 (Tecna, s.r.l, Trieste, Italy) and HPLC equipped by fluorescence detector (Waters Alliance 2695) were applied for determination of Aflatoxin M1 in 60 samples of raw milk. All standard controls were duplicated on a 96-well plate coated with anti-AFM1 antibodies. After colorization, using the appropriate chromogen, the samples were weighed using a microplate Bio-Rad Model 680 (Philadelphia, USA) photometer set at 450 $\mathrm{nm}$. The measured absorption was inversely proportional to the AFM1 concentration in the sample and the measured apparatus ranging from 5 to $250 \mathrm{ng} / \mathrm{kg}$.

\section{Statistical analyses}

The experimental results of the quality of raw milk samples were subject to independent one-way analysis of variance (ANOVA) to examine the impact of each fixed factor (i.e., raw milk samples), on the dependent variables (i.e., the somatic cell count and the amount of adlatoxin M1). The level of significant differences of the mean values ( $p$-value) used was $5 \%$ for all the performed one-way ANOVA and Tukey's tests. When the F-tests resulted in significant differences, the mean values were further subjected to Tukey's-HSD post-doc tests for a comparison of the mean differences between groups of the independent variables (i.e., the total somatic cells and the amount of aflatoxin M1) could be undertaken. The IBM SPSS Statistics v.16.0 software (IBM Corporation, Chicago, IL, USA) was used for the statistical analyses.

\section{RESULTS AND DISCUSSION}

\section{Determination of somatic cell count}

Besides the immune defence role in the udder, SCs can continue their protective function in milk (Gera \& Guha, 2011). Additionally, some components identified as being from SCs are present in milk and also help to enhance the host defence. For example, PMNs have bactericidal and respiratory burst activities and they can eliminate the invading bacteria by releasing reactive oxygen species (ROS) and granular enzymes. According to the results obtained from 482 samples taken once per month, 462 samples meet the National and EU standards for the total number of somatic cells as a parameter for milk quality. The measured average values showed that the highest value of somatic cells count was $277743.90 \mathrm{scc} / \mathrm{mL}$ in June 2018 and the lowest measured average value was detected for March 2018 (233701.3 scc/mL). Furthermore, from 482 samples collected in the "Ovče Pole" region, 95.8\% met the criteria prescribed in the milk and dairy products regulative of 2016 where the maximum number of somatic cells can be $400,000 \mathrm{cfu} / \mathrm{ml}$ in raw cow's milk and are also satisfied and EU milk quality standards. Identification of area-specific and farm-specific risk factors was crucial in cow mastitis control programmes. As we can see from the figure 2, only 6 samples from 72 samples collected in January was above limit of $400,000 \mathrm{cfu} / \mathrm{ml}$. Furthermore, 6 from 76 samples in total collected in February had higher number of somatic cells in raw milk samples. Only one sample from 78 samples of raw milk collected in March and one sample from 84 samples of April did not meet regulative for somatic cells count. The results from examined samples in May indicated 6 samples with higher number of somatic cells and the number of somatic cells in all 83 samples from raw milk collected in June was below 400,000 cfu/ml. From the results above, it can be concluded that the raw milk had good quality (in relation to somatic cell count) and selected exclusively healthy head 
of cattle had a low percentage of mastitis and good control of the mammary gland.

\section{Determination of the amount of} Aflatoxin M1

Determination of the amount of aflatoxin M1 was determined in 60 samples of raw milk. In two samples a concentration higher than $0.05 \mathrm{ng} / \mathrm{kg}$ was detected by ELISA method. The amount of aflatoxin $\mathrm{A} 1 \mathrm{M} 1$ in those two samples were additionally analysed by HPLC with fluorescent detector, as a confirmation method (Galvano et al., 1996). AFM1 concentrations in both samples (3.3\%) exceeded the maximum permissible levels, and the highest detected concentration was $0.58 \mathrm{ng} / \mathrm{kg}$, which is $0.08 \mathrm{ng} /$ $\mathrm{kg}$ above the permissible limit (Ghorbanian et al., 2008).

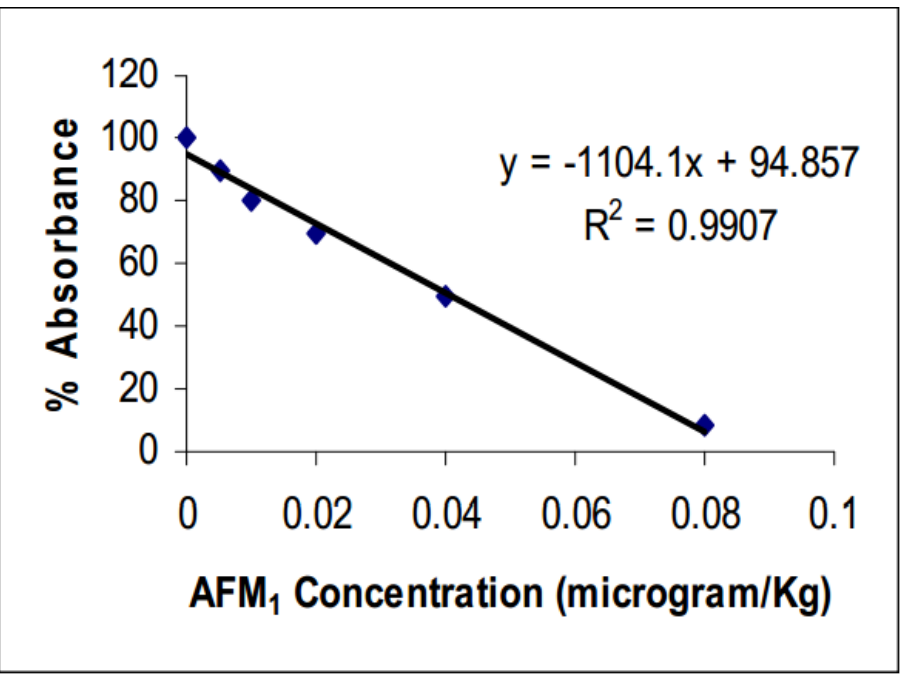

Figure 1. A sample enzyme-linked immunosorbent assay calibration curve.

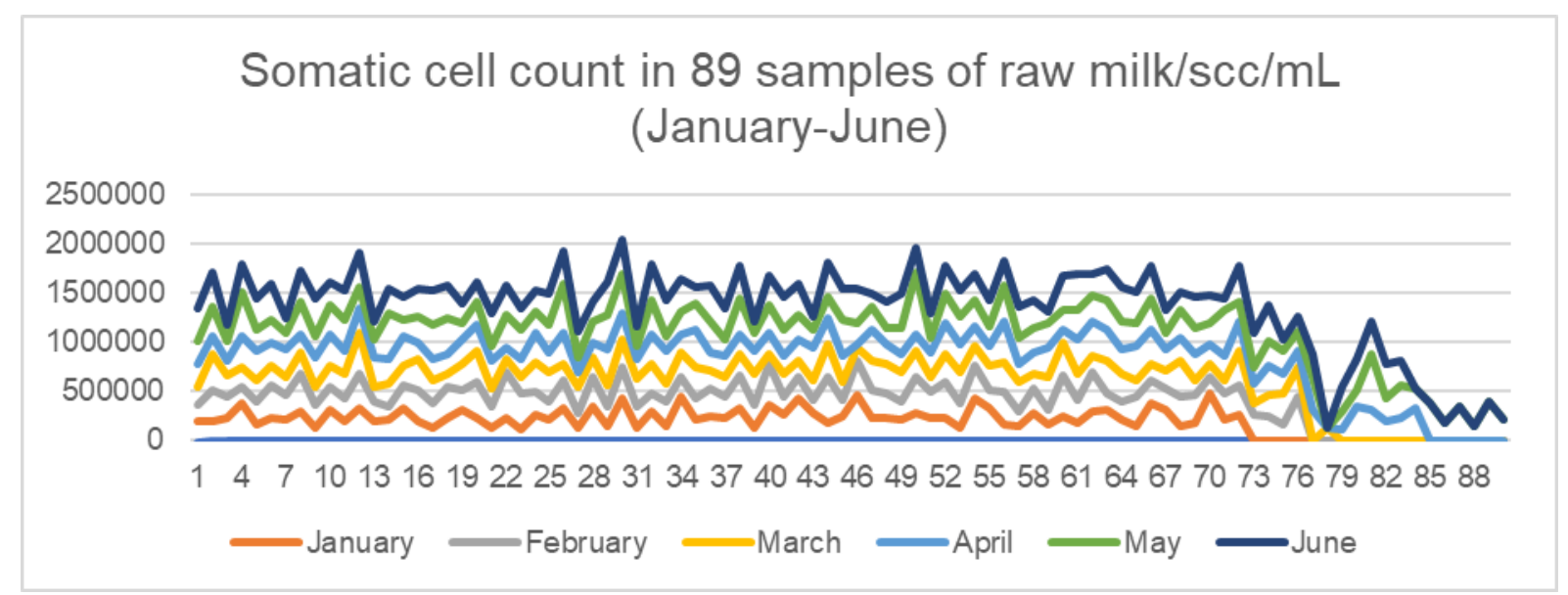

Figure 2. Somatic cell count in 89 samples of raw milk from the "Ovče Pole" region for period January-June,

\section{Total bacterial count}

According to the analysed 1320 samples that were taken twice in the first and second half of the month (analysis 1- 667 samples and analysis 2-653 samples) only 138 samples that meet the national standards while according to the EU (Council Directive 92/46 EEC). Presented by months as the average value of the bacteria were determined in raw milk it is obvious that the average value in January is the lowest with $326069.44 \mathrm{cfu} / \mathrm{mL}$ while in May it is the highest with $623395.6 \mathrm{cfu} / \mathrm{mL}$. 
Table 1. Total bacterial count (average value from January-June, 2018).

\begin{tabular}{|c|c|c|c|c|}
\hline \multicolumn{5}{|c|}{ Total bacteria count in samples of raw milk for the period (January-June 2018 year) } \\
\hline Month & $\begin{array}{c}\text { Number of } \\
\text { samples from } \\
\text { Analyst 1 }\end{array}$ & $\begin{array}{c}\text { Number of } \\
\text { samples from } \\
\text { Analyst 2 }\end{array}$ & Mean value 1 & Mean value 2 \\
\hline January & 80 & 72 & $348860,75^{\mathrm{d}}$ & $326069,44^{\mathrm{d}}$ \\
\hline February & 87 & 81 & $392069,76^{\mathrm{d}}$ & $332160,49^{\mathrm{d}}$ \\
\hline March & 102 & 102 & $464715,68^{\mathrm{c}}$ & $454764,70^{\mathrm{c}}$ \\
\hline April & 124 & 124 & $581274,19^{\mathrm{b}}$ & $538637,09^{\mathrm{b}}$ \\
\hline May & 137 & 137 & $623395,6^{\mathrm{a}}$ & $605548,18^{\mathrm{a}}$ \\
\hline June & 137 & 137 & $538208,82^{\mathrm{b}}$ & $552102,9^{\mathrm{b}}$ \\
\hline
\end{tabular}

Note: Mean values were calculated of two replicates and two analytical measurements. The different superscript letters $(a-d)$ mean significant differences $(p<0.05)$ among the results in the same column in decreasing order.

The results of our research on the samples selected from the Ovče Pole region showed that only $10.45 \%$ meet the criteria according to the Rulebook on amending the rulebook on special requirements for safety and hygiene and the manner of the procedure for performing official controls of milk and dairy products (Official Gazette of the Republic of Macedonia, No. 197 of 28.10.2016) where the limit for the allowed number of bacteria is $400000 \mathrm{cfu} / \mathrm{mL}$, while none of the samples meet the criteria of the European legislation. The highest statistical significance had samples collected in May, while the lowest significant values indicated samples collected from January which can be linked by the temperature fluctuation. According to the findings of $\mathrm{O}^{\prime}$ Connell et his research group, the bulk tank milk can be stored at $2^{\circ} \mathrm{C}$ or $4^{\circ} \mathrm{C}$ for up to $96 \mathrm{~h}$ with minimal deterioration of quality as long as the milk entering the tank has minimal bacterial contamination (O'Connell et al., 2016). Many of microorganisms gain entry to the milk from equipment and/or personnel, zoonotic pathogens can also be introduced into milk from unhealthy animals. As a consequence of this risk, posterization or other treatments are employed to remove disease-causing microorganisms.

\section{CONCLUDING REMARKS}

The results presented in this research showed that the quality of raw milk in relation to the somatic cell counts and the presence of aflatoxin is at a satisfactory level. Monitoring of somatic cell numbers has been simplified by automated cell counters that allow large numbers of milk samples to be evaluated quickly. Somatic cells tend to be higher in afternoon milking's, which undoubtedly occurs because of the shorter milking interval and lesser fluid milk dilution of sloughed epithelial cells. Therefore, increased frequency of milking (three or four times/day) may slightly elevate.

The previous Aflatoxin crisis due to high AFM1 contamination of maize in 2013 has increased the awareness of the food safety risk managers; induced regulatory measures, research, and innovation activities; and reinforced the consciousness of the food business operators. Consequently, they have implemented strict monitoring and regular control along the feed and food chain utilizing the availability of rapid and less expensive detection kits. This self-control and corrective measures at dairy farms resulted in the slow decrease of AFM1 contamination. In the text, the references should be cited as the following examples: Novakov (2001) or (Dumas et al., 2006, 1999). 
The paper remarks the importance among the milk production and food safety, closely related to the assurance of the milk quality and the prevention of milk spoilage. The dairy industry management programmes as for food safety, the milk quality and the dairy products are preventing the microbial contamination.

Actually, dairy farms are to reduce the milk contamination source from udder and the dairy cow herd health status and the production environment, by hygiene practices in the cow herd management and good milk conserving in the raw milk bulk tank. The food hygiene protocols are fundament for to reduce the microbial contamination of the raw milk and pasteurized milk, regarding the health risk by the microbial pathogens in the food borne diseases and bacterial spoilage, source of deteriorating dairy products and milk.

\section{REFERENCES}

Applebaum, R. S.; Brackett, R. E.; Wiseman, D. W.; \& Marth, E. H. (1982). Aflatoxins: toxicity to dairy cattle and occurrence in milk and milk products. Journal of Food Protection, (45):752777.

Aycicek, H., Aksoy, A. \& Saygi, S. (2005). Determination of aflatoxin levels in some dairy and food products which consumed in Ankara, Turkey. Food Control, (16)3, 263-266.

Bansal, B.K., Hamann, J., Grabowski, T.N. \& Singh, K.B. (2005). Variation in the composition of selected milk fraction samples from healthy and mastitic quarters, and its significance for mastitis diagnosis. Journal of Dairy Research, 72(2): 144-152.

Batavani, R.A., Asri, S. \& Naebzadeh, H. 2007. The effect of sub-clinical mastitis on milk composition in dairy cows. Iranian Journal of Veterinary Research, 8(3): 205-211.

Battacone, G.; Nudda, A.; Cannas, A.; Cappio Borlino, A.; Bomboi, G.; \& Pulina, G. (2003). Excretion of aflatoxin M1 in milk of dairy ewes treated with different doses of aflatoxin B1. Journal of Dairy Science, 86:2667-2675.

Decastelli, L.; Lai, J.; Gramaglia, M.; Monaco, A.; Nachtmann, C.; Oldano, F.; Ruffer, M.; Sezian, A. \& Bandirola, C. (2007). Aflatoxins occurrence in milk and feed in Northern Italy during 20042005. Food Control, 18:1263-1266.

Diener, U. L.; Cole, R. J.; Sanders, T. H.; Payne, G. A.; Lee, L. S. \& Klich M. A. (2001). Epidemiology of aflatoxin formation by Aspergillus flavus. Annu. Rev. Phytopathology, 25:249-270

Dragacci, S., Grosso, F., \& Gilbert, J. (2001). Immunoaffinity column clean-up with liquid chromatography for determination of aflatoxin M1 in liquid milk: Collaborative study. Journal of AOAC International, 84(2): 437-443.

Galvano, F.; Galofaro, V.; \& Galvano, G. (1996). Occurrrence and stability of aflatoxin M1 in milk and milk products: a worldwide review. Journal of Food Protection, 10:1079-1090.

Gera, S. \& Guha, A. 2011. Assessment of acute phase proteins and nitric oxide as indicator of subclinical mastitis in Holstein $\times$ Haryana cattle. Indian Journal of Animal Sciences, 81 (10): 1029-1031.

Ghorbanian, M.; Razzaghi-Abyaneh, M.; Allameh, A.; Shams-Ghahfarokhi, M. and Qorbani, M. (2008). Study of the effect ofneem (Azadirachata indiaca) leaf extract on the growth of fungai. Mycosis, 51 (1): 35-39.

Gong, Y.; Hounsa, A.; Egal, S.; Turner, P. C.; Sutcliffe, A. E.; Hall, A. J.; Cardwell, K.; \& Wild, C. P. (2004). Postweaning exposure to aflatoxin results in impaired child growth: a longitudinal study in Benin, West Africa. Environmental Health Perspectives, 112:1334-1338.

Grant, D. W.; \& Carlson, F. W. (1971). Partitioning behavior of aflatoxin M1 in dairy products. Bulletin of the Environmental Contamination and Toxicology, 6, 521-524.

Hameed, K.G.A., Sender, G. \& KorwinKossakowska, A. (2007). Public health hazard due to mastitis in dairy cows. Animal Science Papers and Reports, 25(2): 73-85.

Lin H, Shavezipur M, Yousef A, Maleky F. Prediction of growth of Pseudomonas fluorescens in milk during storage under fluctuating temperature. Journal of Dairy Science. 2016;99(3):1822-1830. DOI: 10.3168/ jds.2015-10179

Kagkli DM, Vancanneyt M, Hill C, Vandamme P, Cogan TM. Enterococcus and Lactobacillus contamination of raw milk in a farm dairy environment. International Journal of Food Microbiology. 2007;114(2):243-251. DOI: 10.1016/S0168-1605(01)00570-0

O'Connell, A, Ruegg, PL. Jordan, K. O'Brien, B. and Gleeson D. The effect of storage 
temperature and duration on the microbial quality of bulk tank milk. Journal of dairy science. 2016;99:3367-3374.

Van Kessel JS, Karns JS, Wolfgang DR, Hovingh E, Jayarao BM, Van Tassell CP, et al. Environmental sampling to predict fecal prevalence of Salmonella in an intensively monitored dairy herd. Journal of Food Protection. 2008;71(10):1967-1973

Viljoen BC. The interaction between yeasts and bacteria in dairy environments. International Journal of Food Microbiology. 2001;69(1-2):37-44

\title{
ВКУПЕН БРОЈ НА БАКТЕРИИ, СОМАТСКИ КЛЕТКИ И ПРИСУСТВО НА АФЛАТОКСИН М1 ВО СУРОВО МЛЕКО ОД РЕГИОНОТ НА ОВЧЕ ПОЛЕ, РЕПУБЛИКА СЕВЕРНА МАКЕДОНИЈА
}

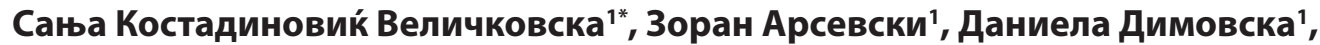 \\ Фиданка Илиева' ${ }^{1}$ Ацо Кузелов ${ }^{1}$ \\ 'Земјоделски факултет, Универзитет „Гоче Делчев“, Крсте Мисирков бб, 2000 Штип, Репиблика Северна \\ Македонија \\ *Контакт автор: sanja.kostadinovik@ugd.edu.mk
}

\section{Резиме}

Мониторингот на квалитетот на млекото и млечните производи започнува од фарма, а завршува во рацете на консументите. Суровото млеко мора да ги задоволи критериумите за квалитет, што подразбира да нема остатоци од лекови, додадена вода, да нема појава на талог, загадувачи или други непожелни контаминенти. Во нашето истражување определивме вкупен број на бактерии, соматски клетки и присуство на афлатоксин М1 во примероци од сурово млеко од Овчеполскиот регион селектирани во период јануари-јуни 2018 година. За потребите на оваа истражување, во 1320 примероци беше определен вкупен број на бактерии, бројот на соматски клетки беше определен во 478 примероци, додека идентификација и квантификација на афлатоксин M1 беше определен во 60 примероци на сурово млеко.

Резултатите од ова истражување покажаа дека 95,5 \% од анализираните примероци го задоволуваат стандардот за бројот на соматски клетки, додека во 2 примерока од сурово млеко имаше детектирано зголемено присуство на афлатоксин М1 со максимално количество од 0,58 mg/kg свежо млеко. Во согласност со Европските стандарди за квалитет на сурово млеко, најголем дел од примероците на сурово млеко од Овчеполски регион во кои се анализираше вкупен број на бактерии (89,55\%) не го задоволуваа стандардот. Резултатите добиени од анализите на сурово млеко индицираа дека фармерите не се придржувале кон добра земјоделска пракса и нивото на контаминација беше високо поради лоша хигиена, несоодветно чување на млекото по молзењето и недоволна едукација на фармерите за хигиена при производство на млеко.

Клучни зборови: сурово млеко, вкупен број на бактерии, вкупен број на соматски клетки, афлатоксин $\mathrm{M1}$ 